\title{
Meta
}

Journal des traducteurs

Translators' Journal

\section{Who Says? A review by Professional Translators of the Work of Students Translating Health Text from English into Italian}

\section{Terry Chesher}

Volume 36, numéro 2-3, juin 1991

URI : https://id.erudit.org/iderudit/002228ar

DOI : https://doi.org/10.7202/002228ar

Aller au sommaire du numéro

Éditeur(s)

Les Presses de l'Université de Montréal

ISSN

0026-0452 (imprimé)

1492-1421 (numérique)

Découvrir la revue

Citer cet article

Chesher, T. (1991). Who Says? A review by Professional Translators of the Work of Students Translating Health Text from English into Italian. Meta, 36(2-3), 352-366. https://doi.org/10.7202/002228ar

\section{Résumé de l'article}

On décrit un projet de traduction où des étudiants en traduction et des praticiens expérimentés travaillent sur un texte traitant du diabète qui est destiné aux itallophones d'Australie. Des spécialistes ont vérifié la version des étudiants et ont apporté des corrections, ou des modifications. Les praticiens décrivent leur façon habituelle de procéder pour la révision des traductions et donnent leurs impressions générales sur les travaux des étudiants. On fournit une liste d'exemples de difficultés relevées à la fois dans le texte anglais de départ, avant et après la traduction en anglais simple et la version en italien faite par les étudiants. Une proposition de schéma sur la précision en traduction est ensuite présentée. 


\section{WHO SAYS? \\ A REVIEW BY PROFESSIONAL TRANSLATORS OF THE WORK OF STUDENTS TRANSLATING HEALTH TEXT FROM ENGLISH INTO ITALIAN}

TERRY CHESHER

University of Queensland, Australia

RÉSUMÉ

On décrit un projet de traduction où des étudiants en traduction et des praticiens expérimentés travaillent sur un texte traitant du diabète qui est destiné aux itallophones d'Australie. Des spécialistes ont vérifié la version des étudiants et ont apporté des corrections, ou des modifications. Les praticiens décrivent leur façon habituelle de procéder pour la révision des traductions et donnent leurs impressions générales sur les travaux des étudiants. On fournit une liste d'exemples de difficultés relevées à la fois dans le texte anglais de départ, avant et après la traduction en anglais simple et la version en italien faite par les étudiants. Une proposition de schéma sur la précision en traduction est ensuite présentée.

\section{ABSTRACT}

A translation project is described involving translation students (non-professionals) and experienced practitioners (professionals) working on a text relating to diabetes, aimed at Italian-speakers in Australia. Professionals were interviewed as they checked the student version of the text, and a number of problems were identified which were considered to need correction or amendment. Practitioners describe their normal procedure when checking translations, and offer general impressions of the students' work. Examples are given of problem areas encountered both in the English SL text before and after pre-translation Plain English editing, and in the students' version of the Italian. A tentative Translation Accuracy schema is outlined.

\section{INTRODUCTION}

The overall goal of the study described was to examine translation in practice, using an authentic translating project of a health translation service as the basis of research. The intention was to explore the process of translation with experienced practitioners whose task was to check a translation recently completed by translation students into Italian. The project was undertaken as the final assignment for an M.A. in Italian language, and also included an examination of the English text before and after editing.

Snell-Hornby (1989: 46) in examining translation theory of the 80's, suggests a new orientation, and notes a common thread discernible in the basic approaches of Honig and Kussmaul (1982) Reiß and Vermeer (1984) and Holz-Manttäri (1984). It is Vermeer who is credited with viewing translation as a "cross-cultural event" (1989:46).

She describes the salient elements as: orientation towards cultural rather than linguistic transfer; translation not as a process of transcoding but an act of communication; 
orientation towards the function of the target text, which is seen as an integral part of the world (not an isolated specimen of language).

Newmark considers that

"the emphasis (is) on the readership and the setting, and therefore on naturalness, ease of understanding and an appropriate register... translation is now used as much to transmit knowledge and to create understanding between groups and nations as to transmit culture". (1988: 9-10)

The need for cross-fertilisation between translation practitioner and theoretician appears to be increasingly recognised in recent years in the field of translation studies, which Bassnett-McGuire describes as

"a new discipline which provides a link between theory and practice".

She feels that the need for systematic study of translation arises directly from the problems encountered during the actual process (Bassnett-McGuire 1987: 134).

Candace Seguinot, addressing the World Congress of Applied Linguistics in Sydney (1987), described the aims of a study she undertook to observe the translation process itself by watching a professional translator work on a typical translation in an administrative setting, and expressed the hope that research into different translation tasks and observations of translators at work will provide us with a better understanding of the strategies used by professional translators.

The present study was intended as a contribution to the field of translation studies, and appears to support the notion of translation in this context as a cross-cultural event.

\section{CONTEXT OF THE PROJECT}

\section{The readership: which Italians?}

As indicated, the text on diabetes has a restricted target group consisting of Italians who have been affected as adults by diabetes. The majority of readers/patients will be first-generation Italians, aged fifty or above, who have been in Australia twenty years or more, and whose knowledge of English may not extend to understanding and complying with treatment and management instructions in English.

According to 1981 census information cited by Di Biase (1987: 58), 4,1\% of Italians in Australia were reported as speaking no English at all. Blewett (1988: 128) cited figures adapted from 1981 census information and 1985 ABS population estimates, recording that there were 78092 Italian-born residents of N.S.W. Bertelli $(1987: 37)$ reports that $37 \%$ of these were 50 years or older in 1981. (The number of second-generation Italian-Australians estimated in 1981 was almost the same: 75 494.)

1986 census data (Australian Bureau of Statistics) indicate that Italians now represent $15 \%$ of the entire N.S.W. population. When asked how well they spoke English, respondents (or presumably their relatives when non-English-speakers were concerned) answered as follows:

\begin{tabular}{lrr} 
very well & 59436 & $54.4 \%$ \\
well & 29444 & $18.4 \%$ \\
not very well & 17660 & $13.5 \%$ \\
not at all & 2800 & $2.5 \%$ \\
\hline
\end{tabular}


The number of Italians in Australia who are reported as speaking no English at all seems to have dropped since 1981 , however it should be noted that the census question in 1981 was worded differently, and asked what language the respondent spoke at home. Furthermore the census information does not indicate whether "language spoken" refers to mastery of written or spoken language. If, as is likely, respondents understood the question to refer to mastery of spoken language, the information will have little relevance to those dealing with the printed word.

\section{The linguistic/cultural context: which Italian?}

The health education information in the text relates to diabetes and its control, and is intended for publication in leaflet form, for distribution to a specific, restricted readership: (diabetic) monolingual Italophones resident in Australia.

The challenge facing translators in Australia working in a health education setting is to produce a text which will be accessible to the greatest number of readers possible. The spoken L1 of most first generation Italians in Australia is dialect, according to Bettoni \& Gibbons, and their spoken L2 regional or popular Italian (Bettoni \& Gibbons 1988: 16). The professional translators in this study translate into Standard Italian, obviously in its written form. Thus it is possible that many readers of the Italian diabetes material will be attempting to read in their second, or even third language.

Translators into Italian have to make generalized presuppositions about the degree of mastery of Italian of readers whose first language may be dialect rather than regional Italian. There may also be a degree of "fossilization" in the locally spoken Italian.

Crystal (1981: 111) suggests that within each culture there are stereotypes and conventions of prestige, propriety and correctness, and emphasises the importance of translators' understanding of cultural attitudes when deciding on a register. He feels

"there is little point in producing a fine, 'professional' translation, if it clashes with the expectations of the majority of the intended audience".

In discussing translation for the Italian community in Australia, Di Biase (1987: 61-62) suggests that the translation process in Australia to some extent presents its own peculiarities which are primarily related to the socio-cultural context of the community for which translations are intended, and that these peculiarities should be/are reflected in translated texts. He feels that in Australia

"the translator must take into account the fact that the readership will inevitably be in fluenced by the linguistic environment in which they are living (i.e. readers speak a minority language in a predominantly English-speaking setting), and the all-pervasive effect of an English-speaking society is bound to affect the Italian of the community".

It is interesting to speculate whether Bettoni \& Gibbons' findings concerning spoken language would apply also to written Italian for the community in Australia. There may be evidence of purism on the part of the professional translators in the present study, however speakers of Italo-Australian may prefer a more traditional Italian to be maintained in written material.

\section{OUTLINE OF THE STUDY}

The SL (English) text under examination was one of a number of translation projects being prepared for publication in community languages. It was approximately 1000 words long. It was originally written by a medical expert (hereafter referred to as the author) to provide essential information to sufferers of diabetes and to their relatives. It was then edited according to Plain English principles by the translation service co-ordinator (T.C.) before translation. 
Normally, two members of a team of professional practitioners translate and crosscheck each text for the translation service, following guidelines which emphasise the preference for "free" translation and accommodating the needs of the specific readership. Cross-checkers are expected to review the full TL text for clarity and comprehensibility, compare the SL and TL texts for accuracy, and collaborate with the translator in the production of a final version.

The text had been translated into Italian by third-year students for a fieldwork assignment. The majority of the students were second generation Italian Australians, attending a course where strong emphasis is placed on translating for the community.

The students will be referred to here as non-professional translators. (This classification reflects the terminology used by Tirkonnen-Condit in her think-aloud protocol study (1987) where she described her first-year students as non-professionals and fifthyear students as professionals). Students had been provided with copies of the translation service's "Guidelines to translators" mentioned above, and the contact number of the health expert for inquiries. The nine students divided the text into three parts, and each group translated one part, then met together to collaborate in the production of a final version.

\section{METHODOLOGY}

For the purposes of the present study, several professional translators (all firstgeneration Italians resident in Australia) were invited to comment individually on the translation into Italian which had been completed by the non-professionals. The proposed amendments and solutions to translation problems provided by the professionals were then reviewed by yet another practitioner, who produced the final Italian TL text by developing a composite version from the alternatives proposed.

In the original research project, all four versions of the text were examined, but the emphasis in the present paper is on problems encountered by the professional translators in reviewing the student translation into Italian. Each of the versions was identified by a separate label: L1.1, L1.2, L2.1 and L2.2.

Table I illustrates the series of operations which was performed in sequence on the text under discussion.

Table 1

\begin{tabular}{|c|c|c|}
\hline & & version \\
\hline Original text & Written by author: medical expert & $\mathrm{L} 1.1$ \\
\hline $\begin{array}{l}\text { Intralanguage } \\
\text { translation }\end{array}$ & $\begin{array}{l}\text { Edited into Plain English } \\
\text { (then approved by author) }\end{array}$ & $\mathrm{L} 1.2$ \\
\hline $\begin{array}{l}\text { Interlanguage } \\
\text { translation }\end{array}$ & $\begin{array}{l}\text { Translated into Italian } \\
\text { (by non-professionals) }\end{array}$ & $\mathrm{L} 2.1$ \\
\hline $\begin{array}{l}\text { Intralanguage } \\
\text { translation }\end{array}$ & $\begin{array}{l}\text { Italian checked/modified } \\
\text { (professional group - }\end{array}$ & $\begin{array}{l}\text { (3 versions) } \\
\text { Checkers } 1,2 \text { \& } 3)\end{array}$ \\
\hline Final version & $\begin{array}{l}\text { Developed from } 3 \text { versions } \\
\text { (professional: Checker } 4 \text { ) }\end{array}$ & $\begin{array}{l}\mathrm{L} 2.2 \\
\text { (final version) }\end{array}$ \\
\hline
\end{tabular}

As indicated, there were three existing texts already when the study was designed. Writing, editing and initial translating of the health information were thus all completed before any consideration was given to their material being studied for research purposes. 
This means that author, editor and non-professional were not aware before completion of their part of the project that their work was to be used as study material. (They were of course subsequently consulted).

\section{Professionals identifying translation problems}

Tirkonnen-Condit (1987: 5) suggests that when translating, or when checking the work of professional colleagues, professionals may make linguistic decisions automatically, and not actually identify them as translation problems.

It was hoped that professional translators, independently checking the work of nonprofessionals, would in the process scrutinise their own linguistic decision-making, and bring to the surface a collection of thoughts and observations about the problems of translation and its inherent challenges. They were asked to describe the changes they proposed as they were making them, and to comment on why they felt the need to make such amendments. Each was asked to describe their normal checking method, and to make any comments they wished on the SL (Plain English) text as well as on the non-professional translation.

It is axiomatic that the translation process, whether undertaken by one or more translators, consists of decisions and revisions, before it assumes whatever form the final arbiter decides on. The purpose of using three experienced translators as checkers in this study, rather than one, was to obtain a small sample of opinions about the problems presented by this particular text from a group of colleagues accustomed to working collaboratively. It was hoped that asking them to provide modifications where they felt the solutions were not entirely satisfactory would provide some insights into the translation process, and demonstrate the multiple choice nature of translating.

\section{Interviews with checkers}

Each of the three checkers was sent a copy of L2.1 (TL - Italian - text) and of L1.2 (SL - Plain English text) a few days before being interviewed. Each was asked to prepare brief written notes giving general impressions of the non-professional translation into Italian, and to be prepared to undertake checking of the text in the presence of the interviewer (T.C.).

Interviews lasting from one and a half to two and a half hours were held on four consecutive days, with no consultation between checkers being interviewed. All checkers agreed to the interviews being recorded on tape, on the understanding that tapes were confidential and were for record purposes only.

All interviews were conducted in Italian, the first language of the checkers, but there was frequent code-switching.

The same procedure was followed at each interview. After a brief explanation by the interviewer of the nature of the study, each checker was asked the following:

- to give a general opinion of the non-professional translation (L2.1);

- to discuss whether the students had succeeded in conveying all the essential messages contained in L1.2 (the edited English text);

- to give their impression of the relative degree of formality of the edited SL and the TL rendition (responses were recorded on a graded scale of $1-5$ );

- to comment on whether they felt that the SL text contained any unacceptably technical terms;

a to describe techniques they routinely use when checking;

- to work through the entire text and to talk out loud as they checked, using whatever procedure they normally followed, and to propose amendments whenever it was felt necessary. 
At each interview, the checker's comments were tape recorded and the final version chosen by each checker for each word, phrase or passage was transcribed onto a clean copy of the students' TL text (L2.1). All the changes the checkers had proposed were later checked against the taped records of interview. Each checker's version was identified by a different colour and all three were copied (distinguished by the same colour) onto another clean copy of the original Italian. Checkers were only identified as Checker 1 , Checker 2 and Checker 3.

Thus the composite version consisted of the non-professional text in its entirety, superscribed with up to three alternative translations provided by the three checkers. The fourth professional was then invited to develop a final version for publication. He was not told whose comments were which and was given the option of selecting one of the multiple alternatives proposed for each term, phrase, or sentence, or to modify it himself if not happy with any of the existing options. The final version was then retyped, and proofread by Checker 4. A copy of the leaflet in final pre-publication form is attached, identified as Diabetes HTS 648 Italian.

In the final stage, the researcher transcribed from the taped interviews relevant comments made by each of the four checkers during interviews. The four versions of the text (the non-professional version, and the three alternative written versions provided by the professionals), are available if of interest. English sentences are identified as S. 1, S. 2 etc. and Italian sentences as Fr. 1, Fr. 2 etc.

\section{OUTCOMES}

There is in all a substantial body of material available, some of which is detailed in the final essay and can be perused if of interest. In this paper I have selected a few examples.

Because the checkers had been asked to talk about the amendment process, instead of just making corrections, they themselves had to analyse their own techniques and the translation principles underlying them. The task of the practitioners was thus not unlike that of the academic who is teaching and examining translation students, the difference being that the professionals in this context were required not only to identify "errors" but also to come up with a fully amended version of the whole text.

\section{Checking procedures}

The professionals followed different procedures as to the manner in which they checked. Checker 1 always reads the TL text first:

"For me it is important to get a sort of feeling between me and the text. If I read from the SL text I get conditioned by it. I read the Italian to hear if it has the cadences, structures and turn of phrase of an Italian text. I highlight any lexical items which appear not to be easily comprehensible to the reader. Then I check with the SL text to see if all the information it contains is in the TL text - to see if it has been translated correctly".

Finally, the TL text is read again, as a piece of Italian, and it is often at this stage that further changes are made.

By contrast, Checkers 2 and 3 read the English first, several times through, "to get a general impression of the subject matter and the register" then commence examining the $\mathrm{TL}$ rendition. It is at this stage that problems begin to emerge.

"I check points of accuracy, like lists, figures, etc. to see there are no omissions. If I change anything I try to restrict myself to essential changes, not just changes for the sake of modifying someone else's style". 
A similar checking pattern emerged for all professionals in terms of the order in which amendments are made once the initial reading is completed.

Firstly, any serious errors or distortions of meaning, including omissions or use of lexical items out of context and anglicisms considered inappropriate are highlighted, and suitable alternatives found and inserted. Next, any ambiguities, including those caused by punctuation are removed or re-phrased to improve the clarity of the messages in the TL.

Finally, the text is usually set aside, and read again at a later stage, in the context of the TL alone. This is the phase where the piece is made to "feel" more Italian, and improvements are made where there is any apparent inconsistency in register. It was when general improvements to style and cohesion were made if needed, or a happy phrase or paraphrase would be found.

[e.g. i]

L.1.2 S. 40

"The treatment should continue indefinitely as although diabetes can be controlled it cannot be cured."

L2.1 Fr. 40

La terapia dovrebbe continuare indefinitamente poichè, sebbene il diabete possa essere controllato, non può essere curato."

L2.2 Fr. 40.

"La terapia va continuata indefinitivamente poichè il diabete è una malattia curabile ma non guaribile."

\section{General impressions of the student product}

All checkers were reasonably satisfied with the standard of the students' work, but when it came to the point, they changed almost every sentence. It was inevitable that each checker would have slightly different solutions to the problems identified. Each of the professionals located and corrected the few serious errors, but there appeared to be more amendments than are normally found when the professionals are checking each others' work.

\section{PROPOSED AMENDMENTS}

Changes related to inaccuracies, ambiguities, repetition or redundancy, and professionals attempted to correct fluctuations in register, as well as constructions which were considered awkward or not appropriate in Italian. Changes appeared to occur especially at the stage of the re-reading of their amended versions. Style changes mostly related to the "flow" of the language where it was felt to be "pesante" (clumsy or pedestrian), or over-literal.

[e.g.ii]

L1.2 (S.23-24):

If this type of diabetes is not carefully treated it may affect the baby. The baby may become very fat, and this can make the mother's labour more difficult.

The non-professional version reads:

L2.1 (Fr. 23-24):

Se questo tipo di diabete non viene curato in maniera appropriata può avere effetti negativi sul neonato. Il bambino può diventare molto grosso e ciò può rendere il parto più difficile.

While the professionals sentence synthesises the two into one:

L2.2 (Fr. 23):

Se questo tipo di diabete non viene curato attentamente può avere effetti negativi sul neonato; il bambino può diventare molto grosso rendendo così il parto più difficile. 


\section{ESSENTIAL SL MESSAGES}

All professionals agreed that the author's messages had been essentially conveyed in the non-professional version, but that certain amendments should be made before the text would be considered of a satisfactory standard for publication and distribution to the Italian-speaking community.

(d) Issues of formality/informality

Asked to grade the degree of formality of the SL text as opposed to the TL text, all professional practitioners felt the Italian was slightly more formal, but observed that this was to be expected of written Italian. The Plain English text deliberately uses personal forms of address, in the hope that such a style would encourage patient involvement in treatment.

Other decisions confronted by translators and/or checkers related to correct forms of address, and consequent degrees of formality and informality, personal and impersonal forms. This was another area where there were differing opinions within the students' group and the within the group of professionals. At a time when in Italy there is extensive use of informal forms of address (i.e. "tu" and "voi") in documents of a similar nature to the text under discussion, the students opted, not without disagreement, for the use of the impersonal "si" form. This choice, which was of course made at the beginning of the translation process, had repercussions throughout the exercise, and appeared to be a departure from the intentionally informal, personal form of the edited SL Plain English version.

[e.g. iii]

\section{L1.1 (S.1)}

Diabetes is a condition that occurs when there is too much sugar in the blood;

L1.2 (S.1)

Diabetes is a condition that can occur if you have too much sugar in your blood;

L2.1 (Fr. 1)

Il diabete è un disturbo che può manifestarsi quando si ha una concentrazione di zucchero (glucosio) nel sangue troppo alta (“...when one has...");

L2.2 (Fr. 1)

Il diabete è un disturbo che può manifestarsi quando il paziente presenta una concentrazione troppo alta di zucchero (glucosio) nel sangue ("...when the patient presents...").

The tenor has shifted from a more personal, informal style, to an impersonal, formal wording increasing the distance between health professional and patient. cal English:

In the next example, the Plain English version was more personal than the medi-

[e.g. iv]

L1.1 (S.21)

The excessive amount of sugar in the blood can cause a number of symptoms:"

L.1.2 (S.29)

You may notice one or more of the following symptoms, which are the result of too much sugar in the blood.

But the non-professionals reintroduced the impersonal usage:

L2.1 (Fr. 29)

Il paziente può notare uno dei seguenti sintomi i quali sono determinati da un livello eccessivo di zucchero; 
and in the professional version the excessive amount of sugar has once more become the subject:

L2.2 (Fr. 29)

Il livello eccessivo di zucchero nel sangue si può manifestare attraverso i seguenti sintomi:"

The professionals had not been unanimous in sanctioning the "si impersonale" form, but in conformity with translation service policy not to make stylistic changes, did not introduce the personal " $t u$ " form. However, two of the checkers frequently commented during their interviews that a lot of problems could have been avoided had the "t $u$ " form been adopted, and the more experienced practitioners found creative solutions to translation problems which had apparently caused problems to the students.

[e.g. v]

L1.2 (S.32)

"If you are worried, go and see your doctor who can check if you are diabetic or not."

L2.1 (Fr. 32)

Chiunque fosse preoccupato può rivolgersi al proprio medico il quale sarà in grado di dire se la persona è affetta o no.

The more elegant professional solution was:

L2.2 (Fr. 32)

In caso di dubbio sarà opportuno rivolgersi al medico il quale sarà in grado di confermare o escludere la presenza del diabete

\section{Comments or changes relating to the SL text (both versions)}

The main changes made by the editor to the author's text related to improvements in the overall organisation of the text, insertion of extra headings, and removal of constructions or terminology considered to be excessively complex. An example follows of the reworking of one sentence of the original text.

[e.g.vi]

L1.1 (S.2)

There are different types of diabetes but all types have in common too much blood sugar resulting from a disorder of the pancreas which makes insulin, the hormone in the body that controls how much sugar is in the blood.

L1.2 (S.2 \& 3)

"The amount of sugar in your blood is controlled by the pancreas, a body organ which produces a substance called insulin. If the pancreas is not working properly and if it does not produce the correct amount of insulin for your body, you may become a diabetic."

\section{L2.1 (S.2 \& 3)}

"La quantità di zucchero nel sangue è regolata dal pancreas, un organo che produce una sostanza chiamata insulina. Il diabete può insere se il pancreas non funziona correttamente $\mathrm{e}$ se non produce l'esatta quantità di insulina necessaria all'organismo."

\section{L2.2 (S.2 \& 3)}

"La quantità di zucchero nel sangue è regolata dal pancreas, l'organo che produce una sostanza chiamata insulina. Il diabete può insorgere se il pancreas non funziona correttamente e non produce l'esatta quantità di insulina necessaria all'organismo."

While the editor achieved a greater structural simplicity, the modified sentence was ambiguous, and this was picked up by one of the professionals, (although not by the nonprofessionals). So in the final Italian "and if" was deleted. 
[Note that in the non-professional translation a more impersonal form was preferred, with the diabetes as the main subject, and this adjustment was retained by the professionals.]

\section{Structure and terminology}

In the opinion of the professionals, the terminology and structure of the edited English was considered satisfactory on the whole, but it was felt there were occasional shortcomings in grammatical logic and constructions, and lapses in cohesion. Experienced translators appear to develop refined skills of logical analysis, and soon detect lexical or grammatical deficiencies in an SL text. It is under such circumstances when the translator detects and corrects infelicities in the SL text, that the author's meaning may become clearer in the TL than it was in the SL original!

It is interesting to note that on a number of occasions where Plain English intentionally reduced the length of sentences, or presented information in point form, one professional in particular strongly objected, asserting that Italian is not written in such short sentences. Another professional, however, criticised the non-professionals for having ignored the point form, and felt that the TL version would have been clearer to the readership if the point form had been retained. It was also this professional who objected to the students' version increasing the distance between author and reader by the substitution of a more impersonal and abstract wording for the original more personal, concrete usages :

[e.g. vii]

L1.1 (S.21-22)

The excessive amount of sugar in the blood can cause a number of symptoms:

- thirst

- excessive urination [etc]

L1.2 (S.21-22)

You may notice one or more of the following symptoms, which are the result of too much sugar in the blood:

1. You may be frequently very thirsty;

2. You may be passing more urine than usual; [etc.]

There were few instances in the medical original where terminology was overcomplex, but the terms used to define types of diabetes: Insulin-dependent diabetes and non-insulin-dependent diabetes could not be edited out, and caused much discussion as to apparent and actual meaning, and presented a challenge both to students and professionals.

[e.g. viii]

L1.2Insulin-dependent diabetes

L2.1Diabete con dipendenza da insulina

L2.2Diabete da insufficienza insulinica

L1.2Non-insulin-dependent diabetes

L2.1Diabete non dipendente da insulina

L2.2Diabete non causato da insufficienza insulinica.

\section{Other problems discussed during checking}

Checkers did not all agree on whether the use of point form in the Plain English should have been retained or amended, and one checker in particular felt that the students, in their attempts to match the simplicity of the English were sometimes inclined to produce an excessively literal reflection of it which did not read well in Italian: 
[e.g.ix]

L1.1 (S.30)

Follow your treatment including your diet as well as possible.

L1.2 (S.42)

1. Follow the treatment you are given as carefully as possible, and keep as closely as you can to the diet planned for you.

L2.1 (Fr. 42)

1. Seguire la terapia quanto più attentamente è possibile e attenersi quanto più possibile alla dieta consigliata.

L2.2 (Fr. 42)

1. Seguire scrupolosamente la terapia, attendosi alla dieta consigliata.

It is interesting to note that on a number of occasions both the first and second Italian versions chosen appeared to be in a more formal, impersonal and abstract register than the Plain English (L1.2) SL text, thus increasing the distance between the author and the readership. Also note that the checkers had not at any stage sighted the original medical (L1.1) text, yet their choices in L2.2 often bore a close resemblance to it, as evidenced in Fr. 29 [e.g.iv] or in L1.1 S.30 L1.2 S.42 and Fr. 42 (both versions) [e.g.ix]

[e.g.x]

L1.2 (S. 33):

If you are attending a public hospital in the city and you need an interpreter, there is a free confidential service available.

\section{L2.1 (Fr. 33)}

Per chi si reca presso un ospedale pubblico in città e ha bisogno di un interprete, esiste un servizio interpreti gratis e riservato

\section{L2.2: (Fr. 33)}

Presso gli ospedali pubblici dell'area metropolitana esiste un servizio interpreti gratuito e del tutto riservato.

It is not possible without a field trial to judge whether the final text is appropriate to the readership or not, and it would be interesting to trial portions of both the professional and the non-professional texts.

\section{Translation accuracy schema}

On the basis of the input from the checkers of this project a Translation Accuracy schema has been tentatively developed as an experiment [see Table II]. The schema is a possible tool for examiners, and has not been trialled or discussed with educators or professional practitioners at this stage. It consists of a continuum between totally misleading communication at one end $(-1)$ and optimum communication $(+10)$ at the other, where the examiner considers that excellent use has been made of the resources of the TL to convey the messages and essence of the SL original. It may have relevance to those involved in assessing translation competence under examination conditions, as means of measuring and comparing performance, and it may be possible to apply it at phrase and sentence level, or possibly to passages as well.

Decisions as to where any given piece of text is placed on the continuum will of course be governed by factors such as context and requirements of the translation concerned, and I have listed some factors which would influence decisions as to "correctness". 


\section{CONCLUSION}

Given that translation is a form of problem-solving, with multiple choice answers, several of which may be "correct" it was not surprising to find how many different versions were discussed during this project. What is of interest is the question of whether Plain English can be translated into Plain Italian, and whether this has occurred in either of the two TL versions. Was the editing into Plain English useful for translatability or not, and does Standard (written) Italian lend itself to simplification?

Is it significant that on several occasions the final Italian version bore a strong resemblance to the original English which the translators and checkers had not seen? Has the tendency on the part of the professionals to remove personal forms created a greater distance between the patient and the health system? If so, does this conform or not to the expectations of the Italian-speaking community in Australia? 
Table 2

Translation accuracy scale

Schema to grade translation accuracy and identify factors influencing satisfactory communication between English-speaking author and NESB reader in a health setting A pilot Continuum from $(-1)$ to $(+10)$ where: $-1=$ misleading information; $0=$ complete distorsion of meaning; $+10=$ optimum communication. (based on observations by practitioners checking an Italian text on diabetes)

\begin{tabular}{|c|c|c|c|}
\hline Alterations & Essential & & Recommended \\
\hline-1 & 0 & & \\
\hline Misleading & Wrong & Ambiguous & Confusing \\
\hline $\begin{array}{l}\text { Total distorsion } \\
\text { of meaning }\end{array}$ & $\begin{array}{l}\text { Incorrect lexical } \\
\text { and/or, grammatical } \\
\text { choices }\end{array}$ & $\begin{array}{l}\text { Ambiguity } \\
\text { confusion, doubt }\end{array}$ & $\begin{array}{l}\text { Literalness } \\
\text { (influenced by } \\
\text { SL) }\end{array}$ \\
\hline $\begin{array}{l}\text { Readership } \\
\text { misunder- } \\
\text { standing } \\
\text { likelihood of } \\
\text { incorrect self- } \\
\text { management } \\
\text { of patient's/ } \\
\text { condition } \\
\text { (possibly life- } \\
\text { threatening in } \\
\text { a health setting) }\end{array}$ & & $\begin{array}{l}\text { possibility of } \\
\text { incorrect self- } \\
\text { management of } \\
\text { patient's condition }\end{array}$ & \\
\hline
\end{tabular}

Influencing factors:

Level of education of readership

Familiarity of readership with standard Italian (written) before migration Language spoken at home now (dialect, regional or standard Italian)

Length of time since migration

Visits to Italy. 


\section{Desirable but not essential}

$+5$

"Correct": Unambiguous but awkward

Understandable but inappropriate to:

- readership

- context

- form of address

- purpose

- register

- degree of formality

- tenor

(e.g. does not convey vocative tone)

- author: reader relationship

\section{Optional}

Unnecessary repetition or redundancy

All messages included

$\begin{array}{lll}\begin{array}{l}\text { Absence of } \\ \text { wrong }\end{array} & \\ \text { confusing } & \text { | choices } \\ \text { inappropriate } & \text { | }\end{array}$

Absence of

confusing
- Unambiguous, clear messages

Approp. to readership

- corresponds to SL

in tone \& "reads" like TL

- uses appropriate constructions and forms

of address of TL to suit

readership in Australia
Not necessary

$+10$

Excellent use of resources of TL to convey messages and spirit of SL original material

(May have improved on cohesion/clarity of SL)

Influence of dominant Language (E) (terms, structures, 'turn of phrase' transfers etc.) Tendancy to purism, retention of language no longer used in Italy, determination to maintain "proper Italian'

Opportunities (or lack of them) for updating language by reading books, magazines from Italy or material published in Australia. 
This study has obviously raised more questions than it answers. It is hoped in the future to trial the non-professional and professional versions of the text with elderly Italian diabetic patients, as without a field study it is not possible to judge which, if either, of the non-professional and professional versions of the text, would be more acceptable to the intended readership.

\section{BIBLIOGRAPHY}

BASSNETT MCGUIRE, S. (1987): Translation Studies, New Accents. London, Methuen.

BETTONI, C. and J. GIBBONS (1986): "Italian Speakers in Australia - Creative in Practice but Traditional in Attitudes", Australian Review of Applied Linguistics, Melbourne.

BETTONI, C. and J. GIBBONS (1988): "Linguistic Purism and Language Shift: a Guise-voice Study of the Italian Community in Sydney", Int. J. Soc. Lang. 72.

CRYSTAL, D. (1981): "Some Current Trends in Translation Theory and Practice", Directions in applied linguistics.

DI BIASE, B. (1987): "Translating for the Community", Australian Review of Applied Linguistics, Series S, No. 4. EAGLESON, R. (1987): Notes: Plain English Seminar, Sydney Nov. 5-6.

KUSSMAUL, P. (1985): "The Degree of Semantic Precision in Translation. Semantics and the Function of Translation", Babel, 1-31.

NEWMARK, P. (1988): A Textbook of Translation, U.K., Prentice Hall International

SEGUINOT, C . (1987): The Translation Process: an Experimental Study, paper presented at AILA World Congress, Sydney, 1987.

SNELL-HORNBY, M. (1988): Translation Studies, an Integrated Approach, John Benjamins, Amsterdam.

TIRKONNEN-CONDIT, S. (1987): Professional vs. Non-professional Translation, a Think-aloud Protocol Study, paper presented at AILA World Congress, Sydney. 